\title{
IN VITRO PRESERVATION OF DATE PALM (PHOENIX DACTYLIFERA L.) EMBRYOGENIC CALLUS
}

\author{
Diab, Mohamed I., Sabah A. Hassanen* and Mahdia F. Gabr \\ Plant Tissue Culture Unit, Department of Genetic Resources, Desert \\ Research Center, El-Matareya, Cairo, Egypt \\ *E-mail: sabah_hassanen@yahoo.com
}

\begin{abstract}
T $n$ vitro medium term conservation of tropical plant
I germplasm is widely used for most plant species. Changes in the physical or chemical conditions had been used as a strategy for reducing the in vitro plant metabolism and prolonging the cultivation period. Embryogenic callus cultures of Oshkingbeel and Friahy date palm cultivars were derived from shoot tip explants using Murashige and Skoog (MS) medium supplemented with 10 $\mathrm{mg} / \mathrm{l}$ dichlorophenoxy acetic acid (2,4-D) and $3 \mathrm{mg} / \mathrm{l}$ 2isopentenyladenine (2iP). Cultures were stored at two temperature (20 and $27 \pm 2^{\circ} \mathrm{C}$ ) in complete darkness. Cultures were also subjected to different osmotic agents (sucrose and sorbitol) at different concentrations $(0.087,0.1,0.2$ or $0.4 \mathrm{M})$, which were added to medium supplemented with $10 \mathrm{mg} / 1$ 2,4-D and $3 \mathrm{mg} / \mathrm{l} 2 \mathrm{iP}$. Every three months of storage up to 15 months, cultures were evaluated for percentage of survived and germinated embryos. After 15 months, the temperature of $20^{\circ} \mathrm{C}$ was more effective for the in vitro conservation of both cultivars concerning survival percentage and number of germinated embryos. At this temperature, after 15 months of storage, the highest survival percentage was 86.7 and $93.3 \%$ for cvs Oshkingbeel and Friahy, respectively. For osmotic agents, after 15 months, the highest survival percentage $(66.7 \%)$ was recorded with sorbitol at $0.4 \mathrm{M}$ or sucrose at $0.2 \mathrm{M}$ for cv Fraihy, whereas $60 \%$ of cv Oshkingbeel cultures were able to survive when preserved on medium containing $0.2 \mathrm{M}$ sucrose. Sorbitol at its different concentrations and $0.2 \mathrm{M}$ sucrose were the most appropriate treatments for maintaining the cultures and increasing the number of germinated embryos of cvs Oshkingbeel and Fraihy cultures after the tested storage periods.
\end{abstract}

Keywords: Date palm, in vitro preservation, temperature, osmotic agents, recovery 
Date palm (Phoenix dactylifera $\mathrm{L}$.) is one of the most important fruit crops cultivated in arid and semi-arid regions. It is distributed throughout the Middle East, North Africa, South Sahel, areas of East and South Africa, Europe and USA (Jain, 2012). Date palm is cultivated for its high productivity and the high nutrient value of its fruits, for preserving ecosystems threatened by desertification and creating the appropriate microclimate for agriculture under arid conditions. In addition, date palm cultivation generates considerable opportunities for rural employment, providing a major source of income for farmers and ensures livelihood and food security of the rural areas (Jain et al., 2011 and Rajmohan, 2011). Also, date palm is one of the most economically important fruit trees grown in Egypt, it tops the list of date's production in the world (Bekheet et al., 2011). Some cultivars of date palm such as Fraihy, Ghazal, Oshkingbeel and Keaeby, from Siwa Oasis, are superior and endangered (Diab, 2013), therefore, it is important to be subjected to an effective conservation strategy.

Preservation via slow growth is a very simple in vitro technique that permits conservation of plants material for periods ranging from six months to five years, depending on species (El-Dawayati et al., 2012). In vitro conservation protocols should promote maximum survival, genetic stability, as well as enable the subculture frequencies of the plant material to be extended. In general, in vitro germplasm banks are maintained under minimal growth conditions, obtained by slowing down the plant metabolism, which is usually achieved by reducing temperature and light intensity, or by modifying the formulations of the culture media, including dilution of mineral elements, modification of sugar concentrations, changes in the use of growth regulators, or the addition of osmotically active compounds (Engelmann, 2011; Yun-peng et al., 2012 and Lambardi and Ozudogru, 2013). This technique is based on reducing the growth rates of the tissue cultured plant and yet increasing the intervals between subcultures (Englemann, 1991). Three basic methods are used in this technique including physical (reduced temperature and light conditions), chemical (using growth retardants; such as an osmotic agent and abscisic acid) and limiting, reducing or increasing the availability of carbohydrate to comparison to the optimal levels of standard culture conditions (Paunescu, 2009; Engelmann, 2011; Yun-peng et al., 2012 and Lambardi and Ozudogru, 2013). Storage under low temperature is one of the major tissue culture techniques used for preservation of plant genetic resources. The temperatures reported for medium-term conservation are usually from $4^{\circ} \mathrm{C}$ to room temperature (Tassy et al., 2006). However, tropical plant species are often cold-sensitive and have to be stored in the range of $15-20^{\circ} \mathrm{C}$ or even

Egyptian J. Desert Res., 64, 83-98 (2014) 
higher, depending on their sensitivity (Paunescu, 2009). Sucrose is considered the most suitable energy source for the plant for in vitro propagation (Yun-peng et al., 2012). It comprises the major proportion of most tissue culture media comparing to the other constituents (Shibli et al., 2006). Also, sucrose could act as an osmotic agent when used at high concentrations in the growth media. Using sucrose as osmotic agent was reported to reduce growth rate, which would lead to decrease water content of the plant cell, and yet the cells volume decreased (Taiz and Zeiger, 2002). Consequently, this decrease in cell volume would result in lower turgor pressure in the cells, and as cell expansion is a turgor-driven process, loss of turgor would result in growth reduction (Taiz and Zeiger, 2002). While, sorbitol is a sugar alcohol, which is systemically used in slow growth conservation protocols (George et al., 2008). When added at elevated levels, sorbitol changes water potential of the culture media, and consequently as sorbitol is taken up by the plants, growth rate is reduced in response to cellular osmotic regulation (Pierik, 1997).

The main objective of slow growth for in vitro preservation of germplasm is to limit the number of subcultures and to maintain the genetic conditions without endangering plant genetic stability. The aim of this study was to evaluate a procedure for in vitro germplasm conservation of Oshkingbeel and Fraihy date palm cultivars by incubation of selected embryogenic callus at 20 and $27^{\circ} \mathrm{C}$ in complete darkness, and investigate the effect of adding different osmotic regulators (sucrose or sorbitol) to culture medium.

\section{MATERIALS AND METHODS}

This study was carried out in the Plant Tissue Culture Laboratory, Genetic Resources Department, Desert Research Center, Cairo, Egypt, during the period from 2011 to 2014.

\section{Establishment of Embryogenic Callus Cultures}

Explants preparation and embryogenic callus induction of Egyptian date palm cvs Oshkingbeel (semi-dry) and Fraihy (dry) were used according to procedures described by Diab (2008). Shoot tips of cvs Oshkingbeel and Fraihy were excised from 20-25 kg and 3-4 years old offshoots of adult female trees grown in Siwa Oasis, Matrouh Governorate, Egypt. Shoot tips were surface sterilized with commercial Clorox $(5.25 \%$ sodium hypochlorite) contained two drops of tween-20 per $100 \mathrm{ml}$ solution (double surface sterilization). Firstly by $3.2 \% \mathrm{NaOCl}$ for $5 \mathrm{~min}$ and secondly by $2.1 \% \mathrm{NaOCl}$ for $20 \mathrm{~min}$, then thoroughly washed twice with sterilized distilled water. One leaf was carefully removed from the shoot tip, followed by immersion in mercuric chloride $\left(\mathrm{HgCl}_{2}\right)$ at $0.05 \%$ for $7 \mathrm{~min}$. Then, they 
were rinsed with sterilized water for five times.

Sterilized shoot tips were cultured on Murashige and Skoog (MS) medium (Murashige and Skoog, 1962) supplemented with $100 \mathrm{mg} / \mathrm{l}$ dichlorophenoxy acetic acid (2,4-D), $3 \mathrm{mg} / \mathrm{l}$ 2-isopentenyladenine (2iP), 40 $\mathrm{mg} / \mathrm{l}$ adenine sulfate, $170 \mathrm{mg} / \mathrm{l} \mathrm{NaH} \mathrm{PO}_{4}, 30 \mathrm{~g} / \mathrm{l}(0.087 \mathrm{M})$ sucrose, $3 \mathrm{~g} / \mathrm{l}$ activated charcoal and $2.5 \mathrm{~g} / \mathrm{l}$ phytagel. Then, cultures were transferred onto MS medium supplemented with $10 \mathrm{mg} / \mathrm{l}$ 2,4-D, $3 \mathrm{mg} / \mathrm{l}$ 2iP, $40 \mathrm{mg} / \mathrm{l}$ adenine sulfate, $170 \mathrm{mg} / 1 \quad \mathrm{NaH}_{2} \mathrm{PO}_{4}, 30 \mathrm{~g} / \mathrm{l}(0.087 \mathrm{M})$ sucrose, $3 \mathrm{~g} / \mathrm{l}$ activated charcoal and $2.5 \mathrm{~g} / \mathrm{l}$ phytagel.

Cultures were incubated at $27 \pm 2{ }^{\circ} \mathrm{C}$ in complete darkness for eight months with regular transfer to the same fresh medium every four weeks. After this period, embryogenic callus was formed (Fig. 1). Moreover, regrowth (recovery) medium for embryo germination was MS medium without any plant growth regulators (PGRs) under the same incubation conditions.
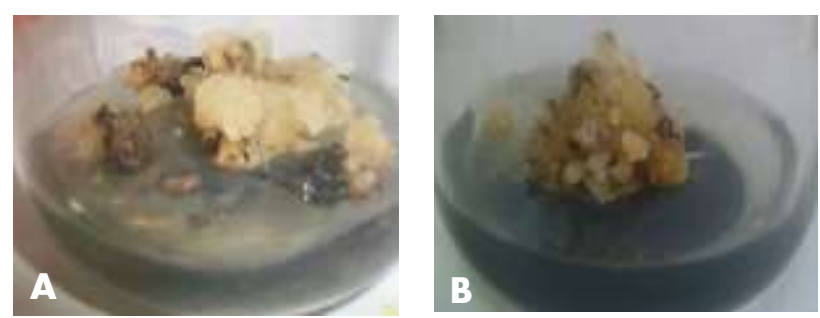

Fig. (1). Embryogenic callus of date palm on MS medium supplemented with $10 \mathrm{mg} / \mathrm{l}$ 2,4-D + $3 \mathrm{mg} / \mathrm{l}$ 2iP; (A) Oshkingbeel cultivar and (B) Fraihy cultivar.

\section{In Vitro Storage}

To extend the period of subcultures of the embryogenic callus, low temperature and osmotic agents were used.

\subsection{Effect of temperature on the embryogenic callus storage}

To test the appropriate temperature for the storage of embryogenic callus of date palm cultivars, equal pieces $(250 \mathrm{mg}$ ) of embryogenic callus were transferred to jars $(350 \mathrm{ml})$ containing $35 \mathrm{ml}$ the previously mentioned medium and then incubated in a growth room at 27 (control) and $20 \pm 2^{\circ} \mathrm{C}$ in complete darkness. Survival percentage of the embryogenic callus and the number of germinated embryos per culture were recorded every three months during the storage periods (15 months).

\subsection{Effect of osmotic agents on the embryogenic callus storage}

To study the effect and role of two types of sugars; sucrose and sorbitol, as osmotic agents, on the storage of embryogenic callus of date palm cultivars, equal pieces $(250 \mathrm{mg})$ of embryogenic callus were transferred to $350 \mathrm{ml}$ jars contained $35 \mathrm{ml}$ of the previously mentioned medium supplemented with $30 \mathrm{~g}$ sucrose, which equals $0.087 \mathrm{M}$ sucrose Egyptian J. Desert Res., 64, 83-98 (2014) 
(control) and different concentrations of sucrose and sorbitol at $0.1,0.2$ or $0.4 \mathrm{M}$. All cultures were incubated in a growth room at $20^{\circ} \mathrm{C}$ in complete darkness. Survival percentage of the embryogenic callus and the number of germinated embryos per culture were recorded every three months during the storage periods (15 months).

\section{Statistical Analysis}

Data were statistically analysed and subjected to the completely randomized design. Each treatment consisted of three replicates, five jars for each replicate and one piece of embryogenesis callus for each jar. Variance analysis of data was carried out using means tested for significance at 5\% level by using Duncan's multiple range test (Duncan,1955) as modified by Snedecor and Cochran (1980).

\section{RESULTS AND DISCUSSION}

\section{Effect of Temperature on the Embryogenic Callus Storage}

The different temperatures influenced the survival percentage of date palm (cvs Oshkingbeel and Fraihy) during in vitro storage periods, as shown in table (1). Survival percentage of embryogenic callus stored in darkness at the temperature of $27 \pm 2^{\circ} \mathrm{C}$ for three months was $100 \%$ for the two cultivars. Results show that embryogenic callus cultures of cvs Oshkingbeel and Fraihy stored at $20^{\circ} \mathrm{C}$ recorded significantly higher survival percentage compared with cultures stored at normal temperature $\left(27 \pm 2{ }^{\circ} \mathrm{C}\right)$. Moreover, at $20^{\circ} \mathrm{C}$ in darkness, when cv Oshkingbeel embryogenic callus was stored for 6 and 9 months and cv Fraihy embryogenic callus was stored for 6, 9 and 12 months, all gave 100\% survival. While, increasing storage duration to 15 months gave survival percentage of embryogenic callus of 86.7 and 93.3\% for cvs Oshkingbeel and Fraihy, respectively (Fig. 2).

From the previous results, it was found that the temperature of $20^{\circ} \mathrm{C}$ was more suitable for storage of date palm embryogenic callus for up to 15 months. The obtained results are in accordance with those reported for the conservation of the germplasm of tropical species, which suggest that the most favorable temperature for the maintenance of these species under minimal growth conditions is between 15 and $20^{\circ} \mathrm{C}$, providing a reduction in metabolic activity and a decrease in growth (Engelmann, 2011). The use of low temperatures in the in vitro maintenance of the germplasm of palm species was previously reported by Bekheet (2011). It is clear that storage of plants under low temperature conditions reduced growth rate as many biochemical activities are slowed down, such as carbohydrate translocation, respiration rates and protein synthesis (Taiz and Zeiger, 2002). Accumulation of unsaturated lipids on the cell membrane would cause cell membrane thickening and retard cell division and elongation (Engelmann, 
1991 and 1997). Meanwhile, the origin of stored species usually determines how cold the storage temperature should be (Engelmann, 1991 and Paunescu, 2009). For example, the tropical plants are usually stored at 15$20^{\circ} \mathrm{C}$ (Paunescu, 2009). Many plants were successfully conserved under low temperature conditions, such as potato (Westcott, 1981), kiwi (Monette, 1986), cassava (Roca et al., 1984) and oil palm (Corbineau et al., 1990).

Table (1). Effect of two temperatures $\left(27\right.$ and $20 \pm 2{ }^{\circ} \mathrm{C}$ ) in darkness on survival percentage of embryogenic callus of date palm cultivars (Oshkingbeel and Fraihy) during 3, 6, 9, 12 and 15 months of in vitro storage.

\begin{tabular}{ccccccc}
\hline Storage & \multicolumn{6}{c}{ Cv Oshkingbeel } \\
\cline { 2 - 7 } temperature & \multicolumn{5}{c}{ Duration of storage (months) } \\
\cline { 2 - 7 }$\left({ }^{\circ} \mathrm{C}\right)$ & $\mathbf{3}$ & $\mathbf{6}$ & $\mathbf{9}$ & $\mathbf{1 2}$ & $\mathbf{1 5}$ & Mean \\
\hline $\mathbf{2 7}$ & $100 \mathrm{a}$ & $80.0 \mathrm{~d}$ & $66.7 \mathrm{e}$ & $66.7 \mathrm{e}$ & $60.0 \mathrm{f}$ & $74.7^{\prime} \mathrm{B}$ \\
$\mathbf{2 0}$ & $100 \mathrm{a}$ & $100 \mathrm{a}$ & $100 \mathrm{a}$ & $93.3 \mathrm{~b}$ & $86.7 \mathrm{c}$ & $96.0^{\prime} \mathrm{A}$ \\
Mean & $100^{\prime} \mathrm{A}$ & $90^{\prime} \mathrm{B}$ & $83.3^{\prime} \mathrm{C}$ & $80^{\prime} \mathrm{C}$ & $73.4^{\prime} \mathrm{D}$ \\
\hline & \multicolumn{5}{c}{ Cv Fraihy } \\
\cline { 2 - 7 } & $\mathbf{3}$ & $\mathbf{6}$ & $\mathbf{9}$ & $\mathbf{1 2}$ & $\mathbf{1 5}$ & Mean \\
\cline { 2 - 7 } & $100 \mathrm{a}$ & $93.3 \mathrm{~b}$ & $80.0 \mathrm{c}$ & $73.3 \mathrm{~d}$ & $66.7 \mathrm{e}$ & $82.7^{\prime} \mathrm{B}$ \\
$\mathbf{2 7}$ & $100 \mathrm{a}$ & $100 \mathrm{a}$ & $100 \mathrm{a}$ & $100 \mathrm{a}$ & $93.3 \mathrm{~b}$ & $98.7^{\prime} \mathrm{A}$ \\
$\mathbf{2 0}$ & $100^{\prime} \mathrm{A}$ & $96.7^{\prime} \mathrm{B}$ & $90^{\prime} \mathrm{C}$ & $86.7^{\prime} \mathrm{D}$ & $73.3^{\prime} \mathrm{E}$ & \\
\hline Mean & &
\end{tabular}

Values with the same letter(s) are not significantly different at 5\% level.
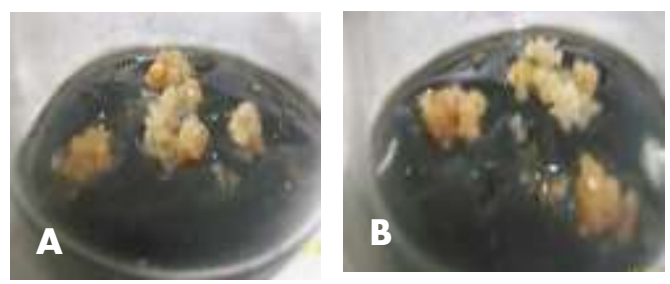

Fig. (2). Embryogenic callus cultures of date palm after 15 months of storage at $20^{\circ} \mathrm{C}$ under complete darkness; (A) Oshkingbeel cultivar and (B) Fraihy cultivar.

Concerning the number of germinated embryos, results illustrated in table (2) show that storage at $20^{\circ} \mathrm{C}$ recorded a higher number of germinated embryos/culture, compared with cultures stored at normal temperature $\left(27 \pm 2^{\circ} \mathrm{C}\right) .$. Storage at $20^{\circ} \mathrm{C}$ for 15 months gave

Egyptian J. Desert Res., 64, 83-98 (2014) 
1.67 and 1.87 embryos/culture of cvs Oshenkingbeel and Fraihy, respectively (Fig. 3).

Storage at normal temperature $\left(27 \pm 2^{\circ} \mathrm{C}\right)$ for 15 months gave the same result for both cultivars ( 0.67 embryos/culture). Generally, recovered embryogenic callus decreased as storage duration increased. The results of the present investigation agree with those reported by Bekheet et al. (2001), who reported that stored date palm emberyogenic callus cultures remained healthy without any serious signs of senescence during different storage periods.

Storage in darkness is very effective for preservation of date palm and increased number of germinated embryos after storage duration. In this regard, plant photosynthesis processes depend on an interplay of light and dark reaction in order to produce the material needed for growth. During dark periods, plants convert the energy contained inside these chemical processes into glucose, the material that fuels plant growth activities (Preece and Read, 2003).

\section{Effect of Osmotic Agents on the Embryogenic Callus Storage}

Effect of osmotic agents (sucrose and sorbitol) concentrations on survival percentage of embryogenic callus, of date palm cvs Oshekingbeel and Fraihy, during in vitro storage at $20^{\circ} \mathrm{C}$ in darkness is presented in table (3). After 3 months of storage, the highest survival percentages of 99.04 and 97.14\% were recorded with cvs Fraihy and Oshekingbeel, respectively. With regard to the effect of different conservation periods, the results indicate clearly that survival percentage decreased gradually from 97.14, $88.57,73.34,50.48$ to $39.04 \%$ for $\mathrm{cv}$ Oshkingbeel by increasing conservation period from $3,6,9,12$ to 15 months, respectively. Concerning the effect of different sugar concentrations, results in table (3) and Fig. (4) reveal that adding $0.4 \mathrm{M}$ sorbitol to the preservation medium resulted in the highest mean value of survival percentage (85.34 for cv Fraihy and 82.66 for cv Oshkingbeel). Data cleared that after 15 months of storage, the highest survival percentage of $\mathrm{cv}$ Oshkingbeel cultured on sucrose at $0.2 \mathrm{M}$ gave $60 \%$ of survived embryogenic callus culture. The highest concentration of sucrose $(0.4 \mathrm{M})$ gave high mortality after 12 months for cv Fraihy or after 12 and 15 months for cv Oshkingbeel, which yielded zero percentage of survival. 
Table (2). Effect of two temperatures $\left(27\right.$ and $\left.20^{\circ} \mathrm{C} \pm 2^{\circ} \mathrm{C}\right)$ in darkness on number germinated embryos per jar of date palm cultivars (Oshkingbeel and Fraihy) during 3, 6, 9, 12 and 15 months of in vitro storage.

\begin{tabular}{ccccccc}
\hline Storage & \multicolumn{7}{c}{ Cv Oshkingbeel } \\
\cline { 2 - 7 } temperature & \multicolumn{7}{c}{ Duration of storage (months) } \\
\cline { 2 - 7 }$\left({ }^{\circ} \mathbf{C}\right)$ & $\mathbf{3}$ & $\mathbf{6}$ & $\mathbf{9}$ & $\mathbf{1 2}$ & $\mathbf{1 5}$ & Mean \\
\hline $\mathbf{2 7}$ & $2.93 \mathrm{c}$ & $2.47 \mathrm{~d}$ & $2.07 \mathrm{e}$ & $1.27 \mathrm{f}$ & $0.67 \mathrm{~g}$ & $1.88 / \mathrm{B}$ \\
$\mathbf{2 0}$ & $4.40 \mathrm{a}$ & $3.73 \mathrm{~b}$ & $2.93 \mathrm{c}$ & $2.13 \mathrm{e}$ & $1.67 \mathrm{f}$ & $2.97 / \mathrm{A}$ \\
Mean & $3.67 / \mathrm{A}$ & $3.10 / \mathrm{A}$ & $2.50 / \mathrm{B}$ & $1.70 / \mathrm{C}$ & $1.17 / \mathrm{D}$ \\
\hline & \multicolumn{7}{c}{ Cv Fraihy } \\
\cline { 2 - 7 } & $\mathbf{7}$ & $\mathbf{6}$ & \\
\cline { 2 - 7 } & $\mathbf{3}$ & $\mathbf{6}$ & $\mathbf{9}$ & $\mathbf{1 2}$ & $\mathbf{1 5}$ & Mean \\
\hline $\mathbf{2 7}$ & $2.47 \mathrm{c}$ & $2.33 \mathrm{c}$ & $2.20 \mathrm{~d}$ & $1.33 \mathrm{e}$ & $0.67 \mathrm{f}$ & $1.80 / \mathrm{B}$ \\
$\mathbf{2 0}$ & $4.93 \mathrm{a}$ & $4.73 \mathrm{a}$ & $3.53 \mathrm{~b}$ & $2.73 \mathrm{c}$ & $1.87 \mathrm{e}$ & $3.56 / \mathrm{A}$ \\
Mean & $3.70 / \mathrm{A}$ & $3.53 / \mathrm{A}$ & $2.87 / \mathrm{B}$ & $2.03 / \mathrm{C}$ & $1.27 / \mathrm{D}$ & \\
\hline
\end{tabular}

Values with the same letter(s) are not significantly at $5 \%$.
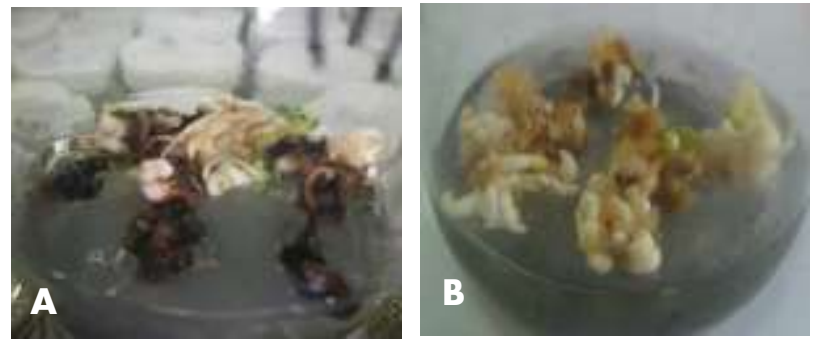

Fig. (3). Germinated embryos of date palm after transferred to normal growth conditions on recovery medium for 6 weeks (The first subculture after removing from storage temperature at $20^{\circ} \mathrm{C}$ (A) Oshkingbeel cultivar (B) Fraihy cultivar. 
Table (3). Effect of osmotic agents on survival percentage of embryogenic callus cultures of date palm cultivars (Oshkinbeel and Fraihy) during 3, 6, 9, 12 and 15 months of in vitro storage at $20^{\circ} \mathrm{C}$ in darkness.

\begin{tabular}{|c|c|c|c|c|c|c|}
\hline \multirow{3}{*}{$\begin{array}{l}\text { Osmotic agents } \\
\text { concentration } \\
\text { (M) }\end{array}$} & \multicolumn{6}{|c|}{ Cv. Oshkingbeel } \\
\hline & \multicolumn{6}{|c|}{ Duration of storage (months) } \\
\hline & 3 & 6 & 9 & 12 & 15 & Mean \\
\hline 0.087 M sucrose & $86.7 \mathrm{c}$ & $73.3 \mathrm{e}$ & $60.0 \mathrm{~g}$ & $46.7 \mathrm{i}$ & $33.3 \mathrm{~d}$ & $60.0^{\prime} \mathrm{D}$ \\
\hline 0.1 M sucrose & $93.3 \mathrm{~b}$ & $73.3 \mathrm{e}$ & $66.7 \mathrm{f}$ & $46.7 \mathrm{i}$ & $33.3 \mathrm{~d}$ & $62.66^{\prime} \mathrm{D}$ \\
\hline 0.2 M sucrose & $100 \mathrm{a}$ & $86.7 \mathrm{c}$ & $86.7 \mathrm{c}$ & $66.7 \mathrm{f}$ & $60.0 \mathrm{~g}$ & $80.02 / \mathrm{B}$ \\
\hline 0.4 M sucrose & $100 \mathrm{a}$ & $86.7 \mathrm{c}$ & $53.3 \mathrm{~h}$ & $00.0 \mathrm{j}$ & $00.0 \mathrm{j}$ & $48.0^{\prime} \mathrm{E}$ \\
\hline 0.1 M sorbitol & $100 \mathrm{a}$ & $100 \mathrm{a}$ & $80.0 \mathrm{~d}$ & $60.0 \mathrm{~g}$ & $46.7 \mathrm{i}$ & $77.34^{\prime} \mathrm{C}$ \\
\hline 0.2 M sorbitol & $100 \mathrm{a}$ & $100 \mathrm{a}$ & $80.0 \mathrm{~d}$ & $60.0 \mathrm{~g}$ & $46.7 \mathrm{i}$ & $77.34^{\prime} \mathrm{C}$ \\
\hline \multirow{2}{*}{$\begin{array}{l}\text { 0.4 M sorbitol } \\
\text { Mean }\end{array}$} & $100 \mathrm{a}$ & $100 \mathrm{a}$ & $86.7 \mathrm{c}$ & $73.3 \mathrm{a}$ & $53.3 \mathrm{~h}$ & $82.66^{\prime} \mathrm{A}$ \\
\hline & $97.14^{\prime} \mathrm{A}$ & $88.57^{\prime} \mathrm{B}$ & $73.34^{\prime} \mathrm{C}$ & $50.48^{\prime} \mathrm{D}$ & $39.04^{\prime} \mathrm{E}$ & \\
\hline \multicolumn{7}{|c|}{ Cv. Fraihy } \\
\hline \multicolumn{7}{|c|}{ Duration of storage (months) } \\
\hline & 3 & 6 & 9 & 12 & 15 & Mean \\
\hline 0.087 M sucrose & $93.3 \mathrm{~b}$ & $80.0 \mathrm{~d}$ & $66.7 \mathrm{f}$ & $53.3 \mathrm{~h}$ & $46.7 \mathrm{i}$ & $68.00^{\prime} \mathrm{D}$ \\
\hline 0.1 M sucrose & $100 \mathrm{a}$ & $86.7 \mathrm{c}$ & $73.3 \mathrm{e}$ & $60.00 \mathrm{~g}$ & $46.7 \mathrm{i}$ & $73.30^{\prime} \mathrm{C}$ \\
\hline $0.2 \mathrm{M}$ sucrose & $100 \mathrm{a}$ & $93.3 \mathrm{~b}$ & $86.7 \mathrm{c}$ & $73.30 \mathrm{e}$ & $66.7 \mathrm{f}$ & $84.00^{\prime} \mathrm{A}$ \\
\hline 0.4 M sucrose & $100 \mathrm{a}$ & $86.7 \mathrm{c}$ & $53.3 \mathrm{~h}$ & $13.30 \mathrm{e}$ & $00.0 \mathrm{j}$ & $50.66^{\prime} \mathrm{E}$ \\
\hline 0.1 M sorbitol & $100 \mathrm{a}$ & $100 \mathrm{a}$ & $86.7 \mathrm{c}$ & $73.30 \mathrm{e}$ & $46.7 \mathrm{i}$ & $81.34^{\prime} \mathrm{B}$ \\
\hline 0.2 M sorbitol & $100 \mathrm{a}$ & $100 \mathrm{a}$ & $86.7 \mathrm{c}$ & $80.00 \mathrm{~d}$ & $53.3 \mathrm{~h}$ & $84.00^{\prime} \mathrm{A}$ \\
\hline 0.4 M sorbitol & $100 \mathrm{a}$ & $100 \mathrm{a}$ & $86.7 \mathrm{c}$ & $73.70 \mathrm{e}$ & $66.7 \mathrm{f}$ & $85.34^{\prime} \mathrm{A}$ \\
\hline Mean & $99.04^{\prime} \mathrm{A}$ & $92.38^{\prime} \mathrm{B}$ & $77.15^{\prime} \mathrm{C}$ & $60.92^{\prime} \mathrm{D}$ & $46.68^{\prime} \mathrm{E}$ & \\
\hline
\end{tabular}

Values with the same letter(s) are not significantly different at 5\% level.
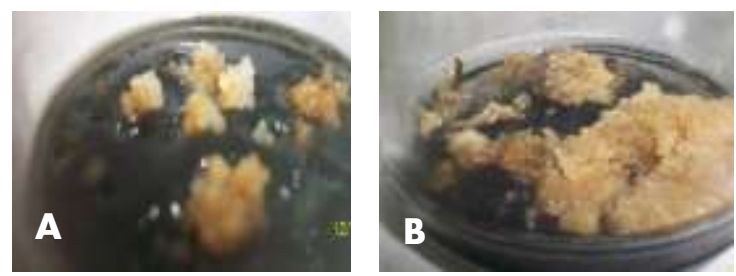

Fig. (4). Embryogenic callus culture of date palm after 15 months of storage on MS medium supplemented with $0.4 \mathrm{M}$ sorbitol at $20^{\circ} \mathrm{C}$ in complete darkness; (A) Oshkingbeel cultivar and (B) Fraihy cultivar.

The present results are in contrast with those reported by BertrandDesbrunais et al. (1992), who found that elevated levels of sucrose were 
successfully used to reduce in vitro growth in many plant species, such as date palm callus culture, $0.1 \mathrm{M}$ sucrose was able to extend subculture intervals and to yield $86.7 \%$ survival after 12 weeks of conservation of the in vitro grown explants (Shibli, et al., 2006).

In addition, plant growth and physiology are highly influenced by carbon source type and content in all tissue culture phases including conservation (Yun-peng et al., 2012). When carbohydrates are added to a culture medium they serve both as carbon sources and as osmotic stressors as they tend to reduce water potential and restrict water availability to the explants (Shibli et al., 2006). The growth rate of in vitro cultures can be limited by various methods including manipulation of the nutritive elements in the culture medium and the use of osmotic regulators and growth retardants, as well as incubation at reduced temperature and/or low light intensity (Engelmann, 2010).

Data in table (4) and Fig. (5) clarify that the highest mean number of embryos germinated per culture was recorded after conservation for 3 months in medium with sucrose or sorbitol (5.79 and 5.58 embryos/culture for cvs Friahy and Oshkingbeel, respectively). Moreover, the lowest number of embryos were observed after conservation for 15 months in medium containing sucrose or sorbitol (2.29 and 2.64 embryos /culture for cvs Oshkingbeel and Fraihy, respectively).

Concerning the effect of sucrose and sorbitol levels on the average number of germinated embryos/culture, there were non-significant differences between all sorbitol concentrations and sucrose at $0.2 \mathrm{M}$ for $\mathrm{cv}$ Oshkingbeel. The highest number of germinated embryos was achieved with sorbitol at $0.4 \mathrm{M}$ for the two cultivars (5.48 and 4.97 embryos /culture for cvs Fraihy and Oshkingbeel, respectively). Explants conserved in medium with $0.4 \mathrm{M}$ sucrose showed the minimum number of germinated embryos (2.27 and 3.04 embryos/culture for cvs Oshkingbeel and Fraihy, respectively). This concentration $(0.4 \mathrm{M}$ sucrose) showed no growth response after transferring in recovery medium for $\mathrm{cv}$ Oshkingbeel embryogenic callus stored for 12 and 15 months and cv Fraihy cultures stored for 15 months. In general, results shows the ability of conserved embryogenic callus to regenerate embryos after transferring and reculturing on recovery medium and incubating under normal conditions, as well as, the average number of germinated embryos/culture decreased significantly with increasing conservation period from 3 to 15 months for both cultivars, regardless of osmotic agents. Also, all concentrations of sorbitol and $0.2 \mathrm{M}$ sucrose gave higher numbers of germinated embryos for both cultivars. Meanwhile, lower sucrose concentrations $(0.087$ and $0.1 \mathrm{M})$ gave lower numbers of germinated embryos ( $<2$ embryos/culture) for both cultivars.

Egyptian J. Desert Res., 64, 83-98 (2014) 
Table (4). Effect of osmotic agent concentrations on number of germinated embryos per culture of date palm cultivars (Oshkinbeel and Fraihy) during 3, 6, 9, 12 and 15 months of in vitro storage.

\begin{tabular}{|c|c|c|c|c|c|c|}
\hline \multirow{3}{*}{$\begin{array}{l}\text { Osmotic agents } \\
\text { concentration } \\
\text { (M) }\end{array}$} & \multicolumn{6}{|c|}{ Cv Oshkingbeel } \\
\hline & \multicolumn{6}{|c|}{ Duration of storage (months) } \\
\hline & 3 & 6 & 9 & 12 & 15 & Mean \\
\hline 0.087 M sucrose & $4.67 \mathrm{c}$ & $3.87 \mathrm{~b}$ & $3.13 \mathrm{~d}$ & $2.53 \mathrm{e}$ & $1.53 \mathrm{f}$ & $3.15^{\prime} \mathrm{B}$ \\
\hline 0.1 M sucrose & $4.80 \mathrm{c}$ & $4.00 \mathrm{c}$ & $3.33 \mathrm{~d}$ & $2.67 \mathrm{e}$ & $1.80 \mathrm{f}$ & $3.32^{\prime} \mathrm{B}$ \\
\hline $0.2 \mathrm{M}$ sucrose & $6.40 \mathrm{a}$ & $5.67 \mathrm{~b}$ & $4.53 \mathrm{c}$ & $4.07 \mathrm{c}$ & $3.00 \mathrm{~d}$ & $4.73^{\prime} \mathrm{A}$ \\
\hline 0.4 M sucrose & $4.60 \mathrm{c}$ & $3.80 \mathrm{~d}$ & $2.93 \mathrm{e}$ & $0.00 \mathrm{~g}$ & $0.00 \mathrm{~g}$ & $2.27^{\prime} \mathrm{C}$ \\
\hline 0.1 M sorbitol & $6.00 \mathrm{a}$ & $5.53 \mathrm{~b}$ & $4.07 \mathrm{c}$ & $3.60 \mathrm{~d}$ & $3.13 \mathrm{~d}$ & $4.47^{\prime} \mathrm{A}$ \\
\hline 0.2 M sorbitol & $6.07 \mathrm{a}$ & $5.53 \mathrm{~b}$ & $4.13 \mathrm{c}$ & $3.73 \mathrm{~d}$ & $3.20 \mathrm{~d}$ & $4.53^{\prime} \mathrm{A}$ \\
\hline 0.4 M sorbitol & $6.53 \mathrm{a}$ & $5.93 \mathrm{~b}$ & $4.73 \mathrm{c}$ & $4.27 \mathrm{c}$ & $3.40 \mathrm{~d}$ & $4.97 / \mathrm{A}$ \\
\hline \multirow[t]{4}{*}{ Mean } & $5.58{ }^{\prime} \mathrm{A}$ & $4.90^{\prime} \mathrm{B}$ & $3.84^{\prime} \mathrm{C}$ & $2.98^{\prime} \mathrm{D}$ & $2.29^{\prime} \mathrm{E}$ & \\
\hline & \multicolumn{6}{|c|}{ Cv Fraihy } \\
\hline & \multicolumn{6}{|c|}{ Duration of storage (months) } \\
\hline & 3 & 6 & 9 & 12 & 15 & Mean \\
\hline 0.087 M sucrose & $4.80 \mathrm{c}$ & $3.84 \mathrm{e}$ & $3.27 \mathrm{c}$ & $2.73 \mathrm{f}$ & $1.87 \mathrm{~g}$ & $3.31^{\prime} \mathrm{C}$ \\
\hline 0.1 M sucrose & $4.87 \mathrm{c}$ & $4.00 \mathrm{~d}$ & $3.33 \mathrm{e}$ & $2.87 \mathrm{f}$ & $1.93 \mathrm{~g}$ & $3.40^{\prime} \mathrm{C}$ \\
\hline $0.2 \mathrm{M}$ sucrose & $6.47 \mathrm{~b}$ & $5.80 \mathrm{c}$ & $4.53 \mathrm{~d}$ & $4.07 \mathrm{~d}$ & $3.13 \mathrm{e}$ & $4.80^{\prime} \mathrm{B}$ \\
\hline 0.4 M sucrose & $4.93 \mathrm{c}$ & $4.07 \mathrm{~d}$ & $3.13 \mathrm{e}$ & $3.07 \mathrm{e}$ & $0.00 \mathrm{~h}$ & $3.04^{\prime} \mathrm{C}$ \\
\hline 0.1 M sorbitol & $6.20 \mathrm{~b}$ & $5.67 \mathrm{c}$ & $4.27 \mathrm{~d}$ & $3.67 \mathrm{e}$ & $3.27 \mathrm{e}$ & $4.62^{\prime} \mathrm{B}$ \\
\hline 0.2 M sorbitol & $6.20 \mathrm{~b}$ & $5.73 \mathrm{c}$ & $4.47 \mathrm{~d}$ & $3.87 \mathrm{e}$ & $3.27 \mathrm{e}$ & $4.71^{\mathrm{B}} \mathrm{B}$ \\
\hline 0.4 M sorbitol & $7.07 \mathrm{a}$ & $6.60 \mathrm{~b}$ & $5.33 \mathrm{c}$ & $4.67 \mathrm{~d}$ & $3.70 \mathrm{e}$ & $5.48^{\prime} \mathrm{A}$ \\
\hline Mean & $5.79^{\prime} \mathrm{A}$ & $5.11^{\prime} \mathrm{B}$ & $4.05^{\prime} \mathrm{C}$ & $3.56^{\prime} \mathrm{C}$ & $2.64^{\prime} \mathrm{D}$ & \\
\hline
\end{tabular}

Values with the same letter(s) are not significantly at $5 \%$ level.
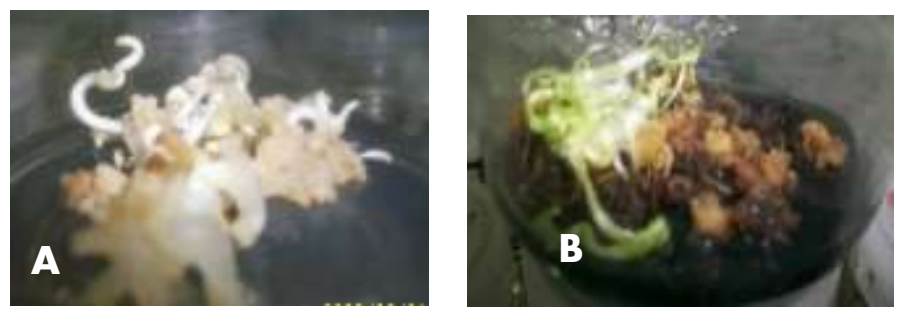

Fig. (5). Germinated embryos of date palm after transferred to normal growth conditions on recovery medium for 6 weeks (The first subculture after removing from storage on sorbitol at $0.4 \mathrm{M}$ ) (A) Oshkingbeel cultivar (B) Fraihy cultivar.

From the pervious results, it is shown that osmotic agents gradually increase the osmotic pressure of the medium and reduce the growth of 
cultures. High concentrations of osmotic agents in the medium cause a negative water potential and reduce the optimal turgor pressure needed for cell division and inhibit growth (Tahtamouni et al., 2001). Also, it may lead to some toxicity (Al-Mahmood et al., 2012). The embryos germination and growth rates were rapidly increased with subculturing every six weeks (Fig. $6)$.
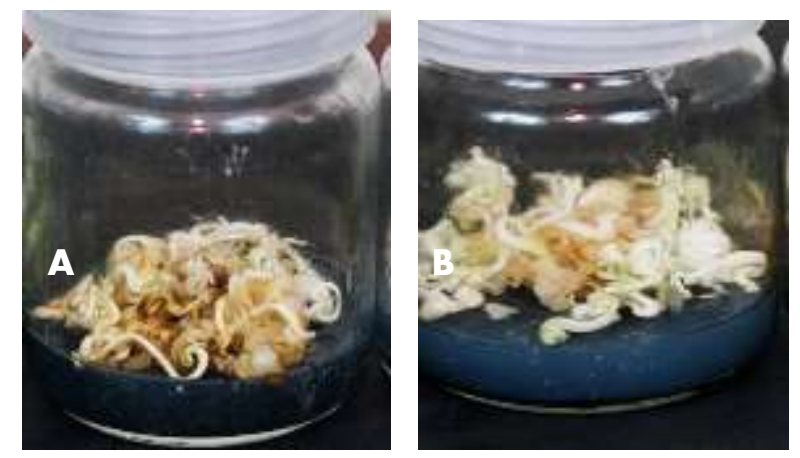

Fig. (6). Success of embryos germination after subculture every six weeks; (A) Oshkingbeel cultivar and (B) Friahy cultivar.

It could be concluded that in vitro storage at 3, 6, 9, 12 and 15 months at temperature of $20^{\circ} \mathrm{C}$ and by using osmotic agents, such as sucrose and sorbitol, affected the growth of the preserved date palm embryogenic callus and their regrowth. The temperature of $20^{\circ} \mathrm{C}$ was more effective for the in vitro conservation of both cultivars up to 15 months. At this temperature, the highest survival percentages were 86.7 and $93.3 \%$ and recorded a higher number of germinated embryos (1.67 and 1.87 embryos/culture) for cvs Oshkingbeel and Friahy, respectively. For osmotic agents, sorbitol at its different concentrations and $0.2 \mathrm{M}$ sucrose were the most appropriate treatments for maintaining the cultures and increasing the number of germinated embryos for both cultivars after the tested storage periods. In this respect, results show the ability of conserved embryogenic callus to regenerate embryos after reculturing on recovery medium and incubating under normal conditions, as well as, the average number of germinated embryos/culture decreased significantly with increasing conservation period from 3 to 15 months for both cultivars, regardless of osmotic agents. Finally, the osmotic agents increase the osmotic potential of the medium, reduce the growth of cultures and extend subculture interval to 15 months. 


\section{REFERENCES}

Al-Mahmood, H.J., M.A. Shatnawi, R.A. Shibli, I.M. Makhadmeh, S.M. Abubaker and A.N. Shadiadeh (2012). Clonal propagation and medium term conservation of Capparis spinosa: plant. Journal of Medicinal Plants Research, 6 (22): 3826-3836.

Bekheet, S.A. (2011). In "In Vitro Conservation of Date Palm Germplasm". Jain S.M.., J.M. Al-khayri and D.V. Johnsan (eds.). Date Palm Biotechnology. Dordrecht, Springer, p. 337-360.

Bekheet, S.A., H.S. Taha and M.M. Saker (2001). In vitro long-term storage of date palm. Biologia Plantarum, 45: 121-124.

Bertrand-Desbrunais, A., M. Noirot and A. Charrier (1992). Slow growth in vitro conservation of coffee (Coffea spp.). Plant Cell Tissue and Organ Culture, 31: 105- 110.

Corbineau F., F. Engelmann and D. Côme (1990). Ethylene production as an indicator of chilling injury in oil palm (Elaeis guineensis Jacq.) somatic embryos. Plant Sci., 71: 29-34.

Diab, M.I. (2008). Biotechnological studies of date palm under Siwa Oasis conditions. Ph.D. Thesis, Genetic Engineering and Biotechnology Research Institute (GEBRI), Sadat city, Minufiya University, Egypt.

Diab, M.I. (2013). In vitro propagation of the endangered date palm (Phoenix dactylifera L.) cv Ghazal. 1. Effect of folic acid and biotin on callus formation and differentiation. American-Eurasian J. Agric. and Environ. Sci., 15 (3): 284-290.

Duncan, D. B. (1955). Multiple range and multiple ' $F$ 'test. Biometri, 11: 142.

El-Dawayati, M.M., Z.E. Zaid and S.F. Elsharabas (2012). Effect of conservation on steroids contents of callus explants of date palm cv. Sakkoti. Australian Journal of Basic and Applied Sciences, 6 (5): 305-310.

Engelmann, F. (1991). In vitro conservation of tropical plant germplasm - a review. Euphytica, 57: 227-243.

Engelmann, F. (1997). In "In Yitro Conservation Methods". Biotechnology and Plant Genetic Resources Conservation and Use. B.V. FordLloyd, Newburry, HJ and JA Callow, (eds.), CABI, Walling ford, UK, 119-162.

Engelmann, F. (2010). Use of biotechnologies for conserving plant diversity. Acta Hort., (ISHS), 812: 63-82.

Engelmann, F. (2011). Use of biotechnologies for the conservation of plant biodiversity. In Vitro Cell. Dev. Biol. Plant, 47: 5-16.

George, E. F., M. A. Hall and G. J. De- Klerk (2008). Plant propagation by tissue culture. Plant Cell Tissue and Organ Culture, 93: 353-355. 
Jain, S.M. (2012). Date palm biotechnology: Current status and prospectivean overview. Emir. J. Food Agric., 24: 386-399.

Jain, S.M., J.M. Al-Khayri and D.V. Johnson (2011). In "Date Palm Tissue Culture: A pathway to Rural Development". Date Palm Biotechnology. Jain S.M., J.M. Al-Khayri, D.V. Johnson (eds.). Springer, Dordrecht.

Lambardi, M. and E. A. Ozudogru (2013). Advances in the safe storage of micropropagated woody plants at low temperature. Acta Hortic., 988: 29-42.

Monette, P.L. (1986). Cold storage of kiwi shoot tips in vitro. HortSci., 21: 1203-1205.

Murashige, T. and F. Skoog (1962). A revised medium for rapid growth and bioassays with tobacco tissue cultures. Physiologia Plantarum, 15: 473- 497.

Paunescu, A. (2009). Biotechnology for endangered plant conservation: A critical overview. Rom. Biotech. Lett., 14: 4095-4103.

Pierik, R. (1997). In Vitro Culture of Higher Plants. Kluwer Academic Publishers. Netherlands, 344 pp.

Preece, J.S. and P.E. Read (2003). Novel methods in micropropagation, Proceedings of the $1^{\text {st }}$ International Symposium on Acclimatization and Establishment of Micropropagated Plants. Acta Hortic., 616: 71-76.

Rajmohan, K. (2011). In "Date Palm Tissue Culture: A pathway to Rural Development". Date Palm Biotechnology. Jain S.M., J.M. AlKhayri, D.V. Johnson (eds.). Springer, Dordrecht.

Roca, W.M., R. Reyes and J. Beltran (1984). Effect of various factors on minimal growth in tissue culture storage of cassava germplasm. In Proceedings of the Sixth Symposium of the International Society for Tropical Root Crops, 441-446 pp.

Shibli, R., M. Shantnawi, W. Subaih and M. Ajlouni (2006). In vitro conservation and cryopreservation of plant genetic resources a review. World J. Agri. Sci., 2: 372-382.

Snedecor, W.G. and W.C. Cochran (1980). Statistical Methods. $7^{\text {th }}$ ed. The Iowa State Univ. Press. Ames, Iowa, U.S.A., 507 pp.

Tahtamouni, R.W., R.A. Shibli and M.M. Ajlouni (2001). Growth responses and physiological disorders in wild pear (Pyrus syriaca Boiss.) during slow growth in vitro preservation on osmostressing media. Plant Tiss. Cult., 11: 415-23.

Taiz, L. and E. Zeiger (2002). In "Plant Physiology". $3^{\text {rd }}$ ed. Sinauer Associates Pubilsher, 690 pp.

Tassy, C., C. Feuillet and P.A. Barret, (2006). Method for the medium-term storage of plant tissue samples at room temperature and successive cycles of DNA extraction. Plant Mol. Biol. Rep., 24.

Egyptian J. Desert Res., 64, 83-98 (2014) 
Westcott, R.J. (1981). Tissue culture storage of potato germplasm. 2. Use of growth retardants. Potat Research, 24: 343.

Yun-peng, D., L. Wen-yuan, Z. Ming-fang, H. Heng-bin and J. Gui-xia (2012). The establishment of a slow growth conservation system in vitro for two wild lily species. African Journal of Biotechnology, 11(8): 247-248. 


\section{الحفظ المعملي للكالس الجنيني لنخيل البلح

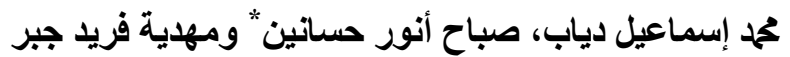 قسم الأصول الور اثية، مركز بحوث أنور الصحر اءو، المطرية، فريد القاهرة، مصر}

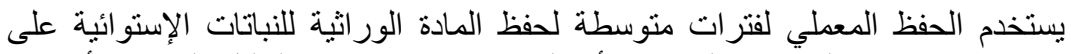

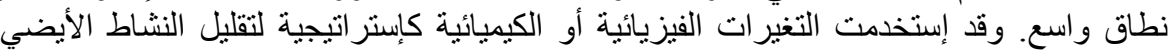

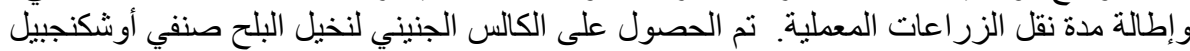

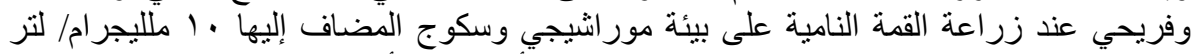

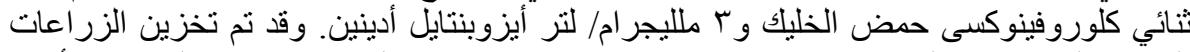

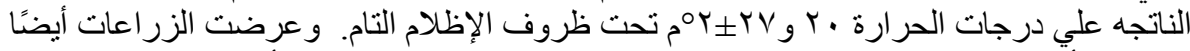

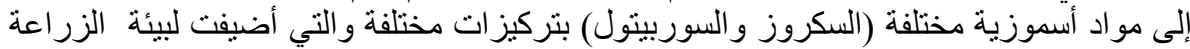

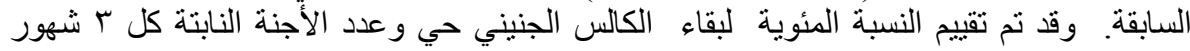

قد أظهرت النتائج أن الحفظ المعملي على درجة حرارة . بوم لمدة 10 شهر كانت أكثر وحتى 10 شهر

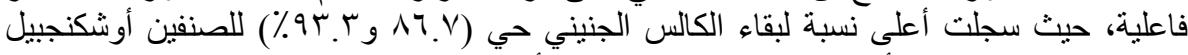

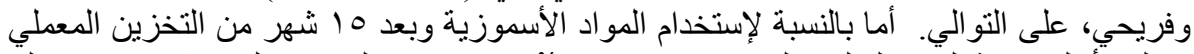

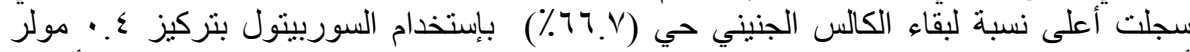

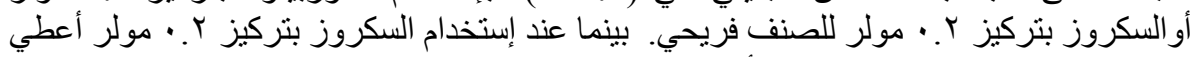

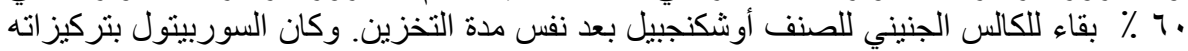

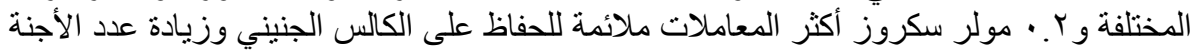
النابتة للصنفين تحت الدر اسة بعد فتر ات ات الحفظ المختبرة.

Egyptian J. Desert Res., 64, 83-98 (2014) 